\title{
EXOGENOUS PHYSIOLOGICALLY ACTIVE SUBSTANCES OF TRICHODERMA HARZIANUM 128 AND THEIR SYNTHESIS WHILE INTRODUCTION OF MICROMYCETES INTO COMPOSTED SUBSTRATE
}

\author{
S. M. Derkach, V. V. Volkohon, V. P. Horban \\ Institute of Agricultural Microbiology and Agroindustrial Manufacture, NAAS \\ 97 Shevchenka str., Chernihiv, 14035; Ukraine; e-mail: volkogon@ukr.net
}

Objective. To study the possibility of production of physiologically active substances by the association of micromycetes Trichoderma harzianum 128, which is used for enrichment composted substrates based on chicken litter. Methods. Microbiological, physiological, accumulative thin layer chromatography, high-performance liquid chromatography (HPLC / MS). Results. T. harzianum 128 produces a significant amount of physiologically active growth stimulanting substances. Soaking of corn seeds in the culture liquid of micromycetes association, diluted with water in 10010,000 times, provides a reliable growth stimulation of seedlings and indicates the absence of phytotoxicity in microorganisms. The instrumental determination of the content of exogenous phytohormones in pre-purified and concentrated phytohormonal extracts shows a significant amount of auxins in a culture fluid - their total amount reaches $18.33 \mu \mathrm{g} / \mathrm{g}$ of dry biomass of the producer, and of cytokinins, in particular, isopentenylidenidine $(5.6 \mu \mathrm{g} / \mathrm{g}$ of dry biomass) and zeatin $(0.88 \mu \mathrm{g} / \mathrm{g}$ dry biomass). Association T. harzianum 128 in small quantities produces gibberellic acids $-G_{3}\left(0.34 \mu \mathrm{g} / \mathrm{g}\right.$ dry biomass) and $G_{4}-0.23 \mu \mathrm{g} / \mathrm{g}$ of dry biomass). Absorbent acid was also found in the culture fluid (5.3 $\mu \mathrm{g} / \mathrm{g}$ dry biomass), but its amount is four times less than the corresponding measures in the known strain T. viride F100001, which was used as a positive control in the studies. While the introduction of association T. harzianum 128 into the composted chicken litter substrate, the obtained compost shows high auxin and cytokinin activity. Conclusion. Phytohormones, which are produced by the micromycetes association of T. harzianum 128, can positively influence the growth and development of plants, play a protective role in adverse environmental conditions. After introduction of the investigated fungi association to a composted substrate on the basis of chicken litter it accumulates significant amounts of physiologically active substances of auxin and cytokinin action. Under these conditions compost acquires new qualitative features.

Key words: Trichoderma harzianum, physiologically active substances, phytohormones, auxins, cytokinins, gibberellins, abscisic acid, composts.

Introduction. Since in the majority of cases the quality and safety of composts for agricultural production is determined by the dominant microbiota, solving the problem of bioconversion of such organic matter as poultry manure is possible by controlling the status of microbial populations during its fermentation. A promising technique may also be the introduction of bacteria and micromycetes to the substrate that can accelerate the composting process, as well as representatives of microbiota beneficial for plant development. This method can not only ensure the waste disposal, but also obtaining efficient and safe bio-organic fertilizers, enriched with beneficial microorganisms and physiologically active substances.

Analysis of recent studies and publications. The possibility of enrichment of composted substrates with microorganisms has been investigated in many scientific centres. Thus, in particular, there were developed composting technologies that include fermentation of organic matter via preliminary heating of the raw material up to $80^{\circ} \mathrm{C}$ followed by its mixing with 
bacterial culture $[1 ; 2]$. In addition to technologies based on the heating of the substrate, there are methods of poultry manure composting under introduction of Klebsiella sp., Bacillus sp., Pseudomonas sp. [3] and other microorganisms to the substrate [4-6].

We believe that the search for microorganisms-biological agents in the processes of composting of organic matter should take into account not only their ability to develop in the substrate and the active mineralization of cellulose, but also the ability to produce physiologically active compounds. Under this condition, the resulting compost may have a number of agronomically valuable properties, including growth-stimulating activity [7]. This is also confirmed by other researchers [8]. Among the microorganisms which exhibit a complex of features important for composting, micromycetes of the genus Trichoderma are promising. Some of their representatives, in addition to cellulosolytic ability, exhibit antibiotic activity and produce other physiologically active substances [6; 8; 9]. Organic composting technologies have been developed using these microorganisms $[6 ; 10]$.

Due to the above, the objective of our studies is to determine the ability of the association of micromycetes Trichoderma harzianum 128 to produce physiologically active substances, which is characterized by high mineralization activity of organic matter while its composting [11].

Materials and methods. The object of the study was the natural association of Trichoderma harzianum 128, comprising two strains: T. harzianum 128/1 and T. harzianum 128/2 [12].

The cultivation of the association was performed by deep method in the periodic culture in glass bottles on a suspended microbiological shaker at the rate of $220 \mathrm{rpm}$ and a temperature of $26 \pm 1^{\circ} \mathrm{C}$. The soybean medium [13] and the Roland-Tom mineral medium [14] were used. Duration of cultivation was 10 days. The titre of micromycetes after fermentation was (5-6) $\times$ $\times 10^{6} \mathrm{CFU}$ in $1 \mathrm{~mL}$.

As a positive control while determining qualitative and quantitative content of phytohormones we used the known strain $T$. viride PersF100001 (biological agent of the biological preparation Trichodermine), kindly provided by the Depository of Microorganisms at D. K. Zabolotny Institute of Microbiology and Virology of the National Academy of Sciences of Ukraine.

In order to determine the biomass of the micromycetes, the spore-mycelium suspension was centrifuged for $20 \mathrm{~min}$ at $9,000 \mathrm{rpm}$. The precipitate was washed from the exopolymer residues with physiological solution three times and centrifuged each time under the same conditions, then dried to a constant weight in a drying oven at $100{ }^{\circ} \mathrm{C}$. The precipitate weight was determined by gravimetric method. The supernatant was used to investigate the effect on growth of corn sprouts [14] and to determine the content of exogenous phytohormonal compounds.

Extracellular auxins, cytokinins, gibberellins and abscisic acid (ABA) were isolated from the supernatants of the cultural fluids of the microorganisms via extraction with the following solvents: ethyl acetate (auxins, ABA), $\mathrm{pH}-$ 3.0; ethyl acetate (gibberellins), $\mathrm{pH}-2.5$; nbutanol (cytokinins), $\mathrm{pH}-8.0[15 ; 16]$. The extracts were evaporated under vacuum at 40 $45^{\circ} \mathrm{C}$. The dry residue was re-dissolved in $80 \%$ ethanol and transferred to the micro-test tubes. The obtained extracts were stored at $-24^{\circ} \mathrm{C}$ and used for cumulative thin-layer chromatography followed by qualitative and quantitative determination of phytohormones by high-performance liquid chromatography (HPLC/MS).

Preliminary purification and concentration of phytohormonal extracts (cumulative thinlayer chromatography) was performed on silica gel plates Silufol UV254 (Chemapol, Czech Republic) in a mixture of solvents used sequentially: chloroform, $12.5 \%$ aqueous ammonia, ethyl acetate : acetic acid $(20: 1)$. The phytohormonal extracts of auxins, cytokinins, gibberellins and abscisic acid thus purified were analyzed by high-performance liquid chromatography (HPLC/MS).

HPLC/MS analysis of phytohormonal extracts of strains of soil microorganisms was performed at the Center for Collective Use at D. K. Zabolotny Institute of Microbiology and Virology of the National Academy of Sciences of Ukraine.

For the comparison we used the standard synthetic phytohormones Sigma (Germany) and Acros Organic (Belgium):

-auxins:

indole-3-acetic acid; indole-3-carboxaldehyde; indole-3-carbinol; 
indole-3-carboxylic acid;

indole-3-acetic acid hydrazide;

indole-3-butyric acid;

- abscisic acid:

abscisic acid;

- cytokines:

zeatin;

trans-Zeatin-riboside;

kinetin;

N 6 -(2-Isopentenyl)adenine;

N 6 -(2-Isopentenyl)adenosine;

- gibberellins:

gibberellic acids $\left(\mathrm{GA}_{3}, \mathrm{GA}_{4}\right.$ and $\left.\mathrm{GA}_{7}\right)$.

The qualitative and quantitative determination of auxins and abscisic acid (ABA) was performed by high-performance liquid chromatography (HPLC) using Agilent 1200 liquid chromatograph (Agilent Technologies, USA). We used Methanol (A) and $1 \%$ acetic acid solution in water (B) as the mobile phase. Separation was performed on Zorbax SB-C18 chromatographic column $(2.1 \mathrm{~mm} \times 150 \mathrm{~mm}, 3 \mu \mathrm{m})(\mathrm{Ag}-$ ilent Technologies, USA), column flow rate was $0.25 \mathrm{~mL} / \mathrm{min}$, thermostat temperature $-30^{\circ} \mathrm{C}$, injection volume $-2 \mu \mathrm{L}$. Elution was performed in gradient mode: $0 \mathrm{~min}-\mathrm{A}(30 \%)$ : : B $(70 \%) ; 25 \mathrm{~min}-\mathrm{A}(30 \%): \mathrm{B}(70 \%)$; $35 \mathrm{~min}-\mathrm{A}(100 \%): \mathrm{B}(0 \%)$.

Compounds were detected using a diode array detector with signal recording at 254 and $280 \mathrm{~nm}$ and absorption spectra fixation in the range of $191-700 \mathrm{~nm}$. Agilent G1956B mass spectrometric detector (Agilent Technologies, USA) was used to determine the molecular weights of the tested pigments. Ionization was performed in ESI and APCI mode with positive ion fixation in SCAN mode in the range of 100$1,200 \mathrm{~m} / \mathrm{z}$. Calibration was performed using standard auxin solutions and ABA.

Qualitative and quantitative determination of cytokinins was performed by high-performance liquid chromatography (HPLC) using Agilent 1200 liquid chromatograph (Agilent Technologies, USA). Methanol (A) and $0.1 \%$ formic acid solution in water (B) was used as the mobile phase. Separation was performed on Zorbax SB-C18 chromatographic column $(2.1 \mathrm{~mm} \times 150 \mathrm{~mm}, 3 \mu \mathrm{m})$ (Agilent Technologies, USA), column flow rate was $0.25 \mathrm{~mL} / \mathrm{min}$, thermostat temperature $-30^{\circ} \mathrm{C}$, injection volume $-2 \mu \mathrm{L}$. Elution was performed in gradient mode: $0 \mathrm{~min}-\mathrm{A}(20 \%)$ : $\mathrm{B}(80 \%) ; 25 \mathrm{~min}-$ A $(70 \%): B(30 \%) ; 35 \mathrm{~min}-\mathrm{A}(100 \%)$ :
: B $(0 \%)$.

Compounds were detected using a diode array detector with signal recording at 254 and $280 \mathrm{~nm}$ and absorption spectra fixation in the range of $191-700 \mathrm{~nm}$. Agilent G1956B mass spectrometric detector (Agilent Technologies, USA) was used to determine the molecular weights of the tested phytohormones. Ionization was performed in ESI and APCI mode with positive ion fixation in SCAN mode in the range of $100-1,200 \mathrm{~m} / \mathrm{z}$. Calibration was performed using standard cytokinin solutions.

The qualitative and quantitative determination of gibberellins was performed by highperformance liquid chromatography (HPLC) using Agilent 1200 liquid chromatograph (Agilent Technologies, USA) and Agilent G1956B mass spectrometric detector. Separation was performed on Zorbax SBC18 column $(2.1 \mathrm{~mm} \times$ $\times 150 \mathrm{~mm}, 3 \mu \mathrm{m})$ (Agilent Technologies, USA), the flow rate of the mobile phase through the column was $0.35 \mathrm{~mL} / \mathrm{min}$, temperature of the column thermostat was $30^{\circ} \mathrm{C}$, injection volume $-3 \mu \mathrm{L}$. The elution was carried out in acetonitrile (A)/water + formic acid (B) system in gradient mode: $20 \%$ of A was kept for $5 \mathrm{~min}$, then changed A content by gradient from 20 to $80 \%$ for 10 min with a subsequent increase of A to $100 \%$ for 0.5 minutes This ratio was kept for the next $8.5 \mathrm{~min}$.

The detection of gibberellins was carried out using a diode-matrix detector with signal recording at 198 and $210 \mathrm{~nm}$. Mass spectrometric analysis was performed with the registration of positive and negative ions in the ratio $\mathrm{m} / \mathrm{z}$ (mass-charge) in the range of $190-400 \mathrm{~nm}$. The fluorescence detector was used at $210 \mathrm{~nm}$ in extinction mode and at $410 \mathrm{~nm}$ in emission mode.

The molecular weights of the studied gibberellins were determined using a single-quadrupole mass spectrometric detector. Ionization was performed in electrostatic spraying (ESI) mode with the formation of negative ions. Ion detection was performed in SCAN and SIM (selected ion monitoring) modes in the range of $200 \div 500 \mathrm{~m} / \mathrm{z}$. GA $3, \mathrm{GA}_{4}$ and $\mathrm{GA}_{7}$ were determined by comparing the retention time, molecular weights of the ions, and the spectral characteristics of the obtained peaks. The quantitative content of $\mathrm{GA}_{3}, \mathrm{GA}_{4}$ and $\mathrm{GA}_{7}$ was determined by the external calibration method by 345,331 and $329 \mathrm{~m} / \mathrm{z}$ ions using SIM mode.

The obtained parameters of phytohormone 
content were calculated per $1 \mathrm{~g}$ of dry biomass of association of fungi T. harzianum 128 and T. viride F100001.

Model experiments on composting poultry manure-based organic substrate were performed in plastic containers, where $5 \mathrm{~kg}$ of poultry manure with a humidity of $60-70 \%$ was introduced. In order to optimize the $\mathrm{C}: \mathrm{N}$ ratio at the level of $20: 1$, milled straw in the amount of $0.7 \mathrm{~kg}$ and peat $-1.9 \mathrm{~kg}$ were added to the manure. A suspension of T. harzianum 128 in the corresponding variant was added to the composted substrate 40 days after the start of composting at the rate of 128 thous CFU/g of dry substrate. The duration of composting was 7 months. Repetition of the experiment is quadruple.

The resulting composts were soaked in tap water in a ration of $1: 16$ for 1 hour, then filtered through a folded paper filter. The presence of phytohormones was studied in aqueous extracts of compost using biotests [15].

Statistical processing of data was performed using a software program (Microsoft Office Excel).

Results and discussion. An important feature of agronomically valuable microorganisms is lack of their phytotoxicity. Bacterial or fungal cultures are considered toxic, when causing a decrease in seed germination of the test culture or inhibition of growth of sprouts and roots by not less than $30 \%$ compared to control [14]. According to the results obtained, native cultural fluid (CF) inhibits the development of corn roots (Table 1).

At the same time, dilution of CF with water promotes root development compared to the control variant (soaking seeds in water). In this case, the effect of CF on root growth is parabolic, which is typical for the action of phytohormones and synthetic stimulants of plant growth and development. The greatest increase in root length was observed during the dilution of $\mathrm{CF}$ in the ratio of $1: 1,000$. The results obtained indicate that the studied association of micromycetes has no phytotoxic properties. Furthermore, fungal CF has a growth-stimulating effect.

Determination of phytohormones in the cultural fluid of micromycetes shows the ability of microorganisms to synthesize these physiologically active substances. Thus, T. harzianum 128 association produces a significant amount of auxins (in total, the amount of indolyl-3-acetic
Table 1. Results of determination of phytotoxicity of T. harzianum 128 fungal association

\begin{tabular}{|l|c|c|}
\hline Variants of experiment & $\begin{array}{c}\text { Length of } \\
\text { the root, cm }\end{array}$ & Af, \% \\
\hline $\begin{array}{l}\text { Control (soaking seeds } \\
\text { in water) }\end{array}$ & 2.69 & - \\
\hline $\begin{array}{l}\text { Soaking seeds in the } \\
\text { digest medium }\end{array}$ & 2.73 & - \\
\hline \multicolumn{2}{|c|}{ Soaking seeds in CF of $T$. harzianum 128} \\
diluted with water: \\
\hline Native CF & 2.52 & 10.0 \\
\hline CF, $1: 10$ & 2.75 & -3.5 \\
\hline CF, $1: 100$ & 2.91 & -13.0 \\
\hline CF, $1: 1,000$ & 3.14 & -26.7 \\
\hline CF, $1: 10,000$ & 2.85 & -9.5 \\
\hline CF, $1: 100,000$ & 2.73 & -2.3 \\
\hline HIP 05 & 0.03 & \\
\hline
\end{tabular}

acid, indole-3-acetic acid hydrazide, indole-3carboxylic acid, indole-3-carbinol is 13.5-fold higher compared the appropriate parameter in T. viride F100001) (Table 2). Auxins are known to be responsible for the correction of a number of processes in the plant organism, the best known of which is rhizogenesis [17]. Furthermore, indole-3-acetic acid hydrazide is able to inhibit the development of phytopathogenic fungi and bacteria [18]. Therefore, we can expect complex effect of biocompost, obtained upon introduction of T. harzianum 128 to the substrate, on the growth and development of crop plants when used in crop cultivation technologies.

It has been established that the studied association of micromycetes is capable of synthesis of isopentenyl-adenine. This substance belonging to the class of cytokinins, is able to stimulate the synthesis of chlorophyll in plants, and therefore can potentially positively affect the process of photosynthesis [19]. Zeatin was found to be much less in the $\mathrm{CF}$ - at the level of $0.88 \mu \mathrm{g} / \mathrm{g}$ of dry matter of the producer (Table 3 ). The production of cytokinins by T. harzianum 128 is inferior to positive control.

The association of T. harzianum 128 was found to produce gibberellic acids - $\mathrm{GA}_{3}$ $(0.34 \mu \mathrm{g} / \mathrm{g}$ of dry matter $)$ and $\mathrm{GA}_{4}-0.23 \mu \mathrm{g} / \mathrm{g}$ of dry matter in small quantities (Table 4). 
Table 2. Content of extracellular auxins in cultural fluid of micromycetes

\begin{tabular}{|l|c|c|c|c|c|c|}
\hline \multirow{2}{*}{ Variants of experiment } & \multicolumn{5}{|c|}{ Content of phytohormones, $\mu \mathrm{g} / \mathrm{g}$ of producer dry matter } \\
\cline { 2 - 7 } & ${ }^{1}$ IAA & ${ }^{2}$ IAA-hydr. & ${ }^{3}$ ICA & ${ }^{4}$ ICal & ${ }^{5}$ IC & total \\
\hline $\begin{array}{l}\text { Control } \\
\text { (soybean digest medium) }\end{array}$ & 0.09 & - & 0.33 & 0.16 & - & 0.58 \\
\hline $\begin{array}{l}\text { T. viride F100001 } \\
\text { (soybean digest medium) }\end{array}$ & 1.02 & - & - & - & 0.34 & 1.36 \\
\hline $\begin{array}{l}\text { T. harzianum 128 } \\
\text { (soybean digest medium) }\end{array}$ & 0.89 & 16.3 & 0.63 & - & 0.51 & 18.33 \\
\hline $\begin{array}{l}\text { T. harzianum 128 } \\
\text { (Roland-Tom digest medium) }\end{array}$ & - & - & 0.40 & - & - & 0.40 \\
\hline
\end{tabular}

Notes: here and in Table 3-5, errors of the arithmetic mean are not provided due to their small values (at the level of $\pm 0.0001-0.0002)$;

${ }^{1}$ IAA — indole-3-acetic acid;

${ }^{2}$ IAA-hydr- - indole-3-acetic acid hydrazide;

${ }^{3}$ ICA - indole-3-carboxylic acid;

${ }^{4} \mathrm{ICal}$ - indole-3-carboxaldehyde;

${ }^{5} \mathrm{IC}$ - indole-3-carbinol.

Table 3. Content of cytokines in the cultural fluid of micromycetes

\begin{tabular}{|l|c|c|c|c|c|}
\hline \multicolumn{1}{|c|}{ Variants of experiment } & Zeatin & $\begin{array}{c}\text { Zeatin- } \\
\text { riboside }\end{array}$ & Kinetin & $\begin{array}{c}\text { Isopentenyl- } \\
\text { adenine }\end{array}$ & $\begin{array}{c}\text { Isopentenyl- } \\
\text { adenosine }\end{array}$ \\
\hline $\begin{array}{l}\text { Control } \\
\text { (soybean digest medium) }\end{array}$ & - & - & - & - & - \\
\hline $\begin{array}{l}\text { T. viride F100001 } \\
\text { (soybean digest medium) }\end{array}$ & - & - & - & 14.2 & - \\
\hline $\begin{array}{l}\text { T. harzianum } 128 \\
\text { (soybean digest medium) }\end{array}$ & 0.88 & - & - & 5.6 & - \\
\hline $\begin{array}{l}\text { T. harzianum } 128 \\
\text { (Roland-Tom digest medium) }\end{array}$ & - & - & - & - & - \\
\hline
\end{tabular}

Table 4. Activity of production of exogenous gibberellins by micromycetes

\begin{tabular}{|l|c|c|}
\hline \multicolumn{1}{|c|}{ Variants of experiment } & $\begin{array}{c}\text { Gibber- } \\
\text { ellic acid } \\
\left(\mathrm{GA}_{3}\right)\end{array}$ & $\begin{array}{c}\text { Gibberel- } \\
\text { lic acid } \\
\left(\mathrm{GA}_{4}\right)\end{array}$ \\
\hline $\begin{array}{l}\text { Control } \\
\text { (soybean digest medium) }\end{array}$ & 0.02 & 0.36 \\
\hline $\begin{array}{l}\text { T. viride F100001 } \\
\text { (soybean digest medium) }\end{array}$ & 0.07 & 0.38 \\
\hline $\begin{array}{l}\text { T. harzianum 128 } \\
\text { (soybean digest medium) }\end{array}$ & 0.34 & 0.23 \\
\hline $\begin{array}{l}\text { T. harzianum 128 (Ro- } \\
\text { land-Tom digest medium) }\end{array}$ & Traces & 0.17 \\
\hline
\end{tabular}

T. harzianum 128 micromycetes association is capable of synthesis of abscisic acid (Table 5). The production of this phytohormone is several times less than that of $T$. viride F100001. It is known that a high content of abscisic acid can inhibit plant growth and development, at the same time it is a known anti-stress substance and its presence in the cultural fluid may indicate the ability to initiate plant resistance to stress conditions using T. harzianum 128-enriched compost.

Phytohormones produced by T. harzianum 128 association can potentially have a positive effect on plant growth and development, and play a protective role under adverse environmental conditions. The ability of T. harzianum 128 association to produce phytohormones may indirectly indicate the possibility of enrichment of the composted substrate by phytohormones, which will positively affect the quality of the finished compost. 
Table 5. Production of abscisic acid by micromycetes

\begin{tabular}{|l|c|}
\hline \multicolumn{1}{|c|}{ Variants of experiment } & $\begin{array}{c}\text { Abscisic acid, } \\
\mu \mathrm{g} / \mathrm{g} \text { dry matter }\end{array}$ \\
\hline $\begin{array}{l}\text { Control } \\
\text { (soybean digest medium) }\end{array}$ & 0.37 \\
\hline $\begin{array}{l}\text { T. viride F100001 } \\
\text { (soybean digest medium) }\end{array}$ & 24.0 \\
\hline $\begin{array}{l}\text { T. harzianum } 128 \\
\text { (soybean digest medium) }\end{array}$ & 5.30 \\
\hline $\begin{array}{l}\text { T. harzianum 128 } \\
\text { (Roland-Tom digest medium) }\end{array}$ & - \\
\hline
\end{tabular}

In this regard, it is necessary to determine their content in compost obtained from T. harzianum 128. However, the instrumental determination of the quantitative composition of phytohormones in compost has significant methodological difficulties. This is primarily due to the high content of humic compound in substrate capable of masking and distorting results. These circumstances led to further research on the use of specific biotests [15].

The obtained results of biotesting indicate the presence of a large number of auxins in the compost obtained under exposure to T. harzianum 128 selected association. When treating wheat coleoptiles with biocompost extract at a dilution of $1: 16,27 \%$ increment in their length is observed relative to control (water treatment) (Table 6).

Table 6. Results of auxin biotest in wheat colleoptiles

\begin{tabular}{|l|c|}
\hline \multicolumn{1}{|c|}{ Variant of experiment } & $\begin{array}{c}\text { Wheat colleoptiles } \\
\text { increment, } \%\end{array}$ \\
\hline Control (water) & - \\
\hline IAA $10^{-5} \mathrm{M}$ & 22.0 \\
\hline $\begin{array}{l}\text { Compost obtained without } \\
\text { microorganism introduction }\end{array}$ & 8.5 \\
\hline $\begin{array}{l}\text { Compost with } \\
\text { T. harzianum } 128\end{array}$ & 27.0 \\
\hline
\end{tabular}

Note: aqueous extract of composts was obtained at water ratio of $1: 16$.

The presence of cytokinins in biocompost was determined by cytokinin biotest on cucumber cotyledons. The results obtained indicate that the weight of the cotyledons increased by $120 \%$ when treated with compost extract ex- posed to T. harzianum 128 relative to the control (Table 7).

Table 7. Results of cytokine biotest in cucumber cotyledons

\begin{tabular}{|l|c|}
\hline \multicolumn{1}{|c|}{ Variants of experiment } & $\begin{array}{c}\text { Increment in } \\
\text { cucumber cotyle- } \\
\text { don weight, \% }\end{array}$ \\
\hline Control (water) & - \\
\hline BAP $10^{-4} \mathrm{M}$ & 196.3 \\
\hline $\begin{array}{l}\text { Compost obtained without } \\
\text { microorganism introduction }\end{array}$ & 74.0 \\
\hline $\begin{array}{l}\text { Compost with } \\
\text { T. harzianum } 128\end{array}$ & 120.1 \\
\hline
\end{tabular}

Note: aqueous extract of composts was obtained at water ratio of $1: 16$.

It should be noted that compost obtained without the introduction of micromycetes is significantly inferior to experimental compost in terms of both auxins and cytokinins.

The results of gibberellin biotest on corn mesocotyles showed that gibberellins in compost are present in small quantities. This correlates with data on the content of exogenous gibberellins in T. harzianum 128 cultural fluid.

Thus, the results of biotests demonstrate that the introduction of T. harzianum 128 to compost contributes to the accumulation of phytohormones of the auxin and cytokinin nature.

Conclusion. T. harzianum 128 micromycetes association is capable of synthesizing exogenous phytohormones, which can have a positive effect on plant growth and development, and play a protective role under adverse environmental conditions. Upon the introduction of the studied fungi association to the composted substrate, compost accumulates significant amounts of physiologically active substances, which indicates the achievement of new, positive features for optimization of the production process of crops by biofertilizer.

\section{REFERENCES}

1. Pat. $2360893 \mathrm{Ru}, \mathrm{MPK}$ C05F3/00, C05F11/10. Bioorganic fertilizer, Mokhov, V. V., Fomichiova, Ye. V., Publ. 10.07.2009 [in Russian].

2. Pat. $2322427 \mathrm{Ru}$, MPK C05F11/08, C12N1/20. Way of biological processing of chicken litter, $\mathrm{Ku}-$ lahina, Ye. M., Yehorov, S. Yu., Publ. 20.04.2008 [in Russian].

3. Pat. $2057103 \mathrm{Ru}, \mathrm{MPK}$ C05F3/00, C05F11/08. 
Biocompost, Sidorenko, O. D., Publ. 27.03.1996 [in Russian].

4. Pat. $2437864 \mathrm{Ru}, \mathrm{MPK}$ C05F11/08, C05F3/00, $\mathrm{A} 01 \mathrm{C} 3 / 00$. Way of microbiological processing of poultry manure, Dmitriiev, V. I., Martynova, I. V., Kochkina, L. I., Publ. 27.12.2011 [in Russian].

5. Pat. $2522523 \mathrm{Ru}, \mathrm{MPK} \mathrm{C} 05 \mathrm{~F} 11 / 08$. Way of microbiological processing of poultry manure, Tremasov, M. Ya., Matrosova, L. Ye., Ivanov, A. A., Titova, V. Yu., Ivanov, A. V., Tremasova, A. M., Semenov, E. I., Publ. 20.07.2014 [in Russian].

6. Blaya, J., López-Mondéjar, R., Lloret, E., Pascual, J., \& Ros, M. (2013). Changes induced by Trichoderma harzianum in suppressive compost controlling Fusarium wilt. Pesticide biochemistry and physiology, 107(1), 112-119. https://doi.org/ 10.1016/j.pestbp.2013.06.001

7. Hatsenko, M. V., Volkohon, M. V., Lutsenko, N. V., \& Volkohon, V. V. (2011). Vplyv Pseudomonas putida 17 na nakopychennia fitohormoniv $\mathrm{u}$ vermykomposti [Influence of Pseudomonas putida 17 on accumulation of phytohormones in vermicompost]. Silskogospodarska mikrobiologia - Agricultural Microbiology, 13, 82-91 [in Ukrainian].

8. Sharma, A., Saha, T. N., Arora, A., Shah, R., \& Nain, L. (2017). Efficient microorganism compost benefits plant growth and improves soil health in calendula and marigold. Horticultural Plant Journal, 3(1), 67-72. https://doi.org/10.1016/j.hpj.2017.07.003

9. Bernal, V. A., Pascual, J. A., \& Tittarelli F. (2015). Trichoderma harzianum T-78 supplementation of compost stimulates the antioxidant defence system in melon plants. J. Sci Food Agric., 95(11). 2208-2214. https://doi.org/10.1002/jsfa.6936

10. Pat. 113809 UA, MPK C05F15/00, C05F11/02, C05F11/08, C05F 17/00, C12R 1/885. Bioorganic fertilizer, Volkohon, V. V., Derkach, S. M., Dimova, S. B., Miahka, M. V., Nakonechna, L. T., Lutsenko, N. V., Publ. 10.03.2017 [in Ukrainian].

11. Volkohon, V. V., Dimova, S. B., Miahka, M. V., Derkach, S. M., Lutsenko, N. V., Shtan'ko, N. P., \& Tsentylo, L. V. (2016). Biokompostuvannia ptashynoho poslidu asotsiatsiieiu hrybiv Trichoderma harzianum 128 [Bioenrichment of poultry manure by association of a fungus Tricho- derma harzianum 128]. Visnyk ahrarnoi nauki Bulletin of Agricultural Science, 11, 13-18. https://doi.org/10.31073/agrovisnyk201611-02 [in Ukrainian].

12. Derkach, S. M., Miahka, M. V., Volkohon, V. V., Nakonechna, L. T., Dimova, S. B., Kravchenko, N. O., \& Lutsenko, N. V. (2018). Morphological and cultural, physiological and biochemical peculiarities of micromycetes strains including in the composition of Trichoderma harzianum 128 association. Silskogospodarska mikrobiologia - Agricultural Microbiology, 28, 17-26. https://doi.org/ 10.35868/1997-3004.28.17-26 [in Ukrainian].

13. Drohoboz, I. V., Yavorskaia, V. K., Antoniuk, V. P., \& Kurchyi, B. A. (2009). Hormonalnyie soiedinienia, produtsyruiemyie assotsiatsiiei mikroorhanizmov iz rizosfery zhenshenia [Hormonal compounds produced by the association of microorganisms from the ginseng rhizosphere]. Fisiologia $i$ biokhimia kult. rastienii - Physiology and biochemistry of cultivated plants, 41(5), 393-399 [in Russian].

14. Bilai, V. I. (Ed.). (1982). Metody eksperimentalnoi mikologii: sprovochnik [Methods of experimental mycology: guide]. Kyiv [in Russian].

15. Metodicheskiie rekomendatsii po opredilieniiu fitogormonov [Guidelines for the determination of phytohormones]. (1982). Kiev [in Russian].

16. Lee, I. J., Foster, K. R., \& Morgan, P. W. (1998). Photoperiod control of gibberellin levels and flowering in sorghum. Plant Physiol, 116(3), 10031011. https://doi.org/10.1104/pp.116.3.1003

17. Polievoi, V. V. (1982). Fitogormony [Phytohormones]. Leningrad : LGU [in Russian].

18. Borzova, N. V., \& Varbanets, L. D. (2009). Tseliulozodehraduiuchi systemy mikroorhanizmiv: biosyntez, vlasyvosti ta strukturnofunktsionalni osoblyvosti [Cellulose-degradative systems of microorganisms: biosynthesis, properties and structural functional features]. Biotekhnolohiia - Biotechnologia Acta, 2(2), 23-41 [in Russian].

19. Averina, N. G., \& Yaronskaia, Ye. B. (2012). Biosyntez tetrapirrolov $v$ pastieniiakh [Biosynthesis of tetrapyrroles in plants]. Minsk : Bielarus. Nauka [in Russian]. 


\title{
ЕКЗОГЕННІ ФІЗІОЛОГІЧНО АКТИВНІ РЕЧОВИНИ TRICHODERMA HARZIANUM 128 TA ÏХ CИНTE3 ЗА IНTРОДУКЦIї МІКРОМІЦЕТІВ ДО КОМПОСТОВАНОГО СУБСТРАТУ
}

\author{
С. М. Деркач, В. В. Волкогон, В. П. Горбань \\ Інститут сільськогосподарської мікробіології та агропромислового виробництва НААН, м. Чернігів \\ e-mail: volkogon@ukr.net
}

Мета. Дослідити можливість продукування фізіологічно активних речовин асочіацією мікроміцетів Trichoderma harzianuт 128, яка використовується для збагачення компостованих субстратів на основі курячого посліду. Методи. Мікробіологічні, фізіологічні, накопичувальної тонкошарової хроматографії, високоефективної рідинної хроматографії (HPLC/MS). Результати. T. harzianum 128 продукує значну кількість фізіологічно активних рістстимулювальних речовин. Замочування насіння кукурудзи у культуральній рідині асочіаиії мікроміцетів, розбавленій водою у 100-10 000 разів, забезпечує достовірне стимулювання росту проростків і свідчить про відсутність фітотоксичності у мікроорганізмів. Інструментальне визначення вмісту екзогенних фітогормонів у попередньо очищених $і$ сконцентрованих фітогормональних екстрактах свідчить про значну кількість ауксинів у культуральній рідині - їх сумарна кількість сягає 18,33 мкг/2 сухої біомаси продуцента - та ичитокінінів, зокрема, ізопентеніладеніну (5,6 мкг/2 сухої біомаси) $i$ зеатину (0,88 мкг/2 сухої біомаси). Асоиіація T. harzianum 128 у незначних кількостях продукує гіберелові кислоти ГКз (0,34 мкг/2 сухої біомаси) і ГК - 0,23 мкг/г сухої біомаси). У культуральній рідині також виявлено абсцизову кислоту (5,3 мкг/2 сухої біомаси), проте ї̈ кількість у чотири рази менша за відповідний показник у відомого штаму T. viride F100001, який використовували в дослідженнях як позитивний контроль. За інтродукиії до компостованого субстрату на основі курячого посліду асочіачіï T. harziaпит 128 отриманий компост проявляе високу ауксинову та иитокінінову активність. Висновки. Фітогормони, щуо продукує асоціація мікроміиетів T. harzianum 128, можуть позитивно впливати на ріст і розвиток рослин, відігравати захисну роль за несприятливих умов навколишнього середовища. За інтродукції досліджуваної асочіачії грибів до компостованого субстрату на основі курячого посліду у ньому накопичуються значні кількості фізіологічно активних речовин ауксинової та циитокінінової діі. За цих умов компост набуває нових якісних ознак.

Ключові слова: Trichoderma harzianum, фізіологічно активні речовини, фітогормони, ауксини, циитокініни, гіббереліни, абсиизова кислота, компости.

\section{ЦИТОВАНА ЛІТЕРАТУРА}

1. Биоорганическое удобрение: пат. 2360893 Российская Федерация. МПК С05F3/00, C05F11/10, В. В. Мохов, Е. В. Фомичёва; заявители и патентообладатели: $\quad$ В. В. Мохов, Е. В. Фомичёва. №2007144781/12; заявл: 03.12.2007; опубл. 10.07.2009, Бюл. № 11 .

2. Способ биологической переработки птичьего помета: пат. 2322427 Российская Федерация. МПК С12N1/20, CO5F11/08, Е. М. Кулагина, С. Ю. Егоров, С. А. Азизов, В. П. Барабанов; заявитель и патентообладатель: ООО «Байлык». №2006126973/13; заявл. 14.07.2006; опубл. 20.04.2008, Бюл. № 11.

3. Биокомпост: пат. 2057103 Российская Федерация. МПК C05F 3/00, C05F11/08, О. Д. Сидо- ренко; заявитель и патентообладатель: Сидоренко О. Д. № 93050107/15; заявл. 02.11.1993; опубл. 27.03.1996, Бюл. № 10.

4. Способ микробиологической переработки птичьего помета: пат. 2437864 Российская Федерация. МПК С05F11/08, С05F3/00, А01C3/00, В. И. Дмитриев, И. В. Мартынова, Л. И. Кочкина; заявитель и патентообладатель: ООО «Микробиотех». № 2010133029/13; заявл. 05.08.2010; опубл. 27.12.2011, Бюл. № 36.

5. Способ микробиологической переработки птичьего помета: пат. 2522523 Российская Федерация. МПК C05F11/08, М. Я. Тремасов, Л. Е. Матросова, А. А. Иванов, В. Ю. Титова, А. В. Иванов, А. М. Тремасова, Э. И. Семенов; заявитель и патентообладатель: ФГБУ «ФЦТРБ- 
ВНИВИ». № 2013101084; заявл. 09.01.2013; опубл. 20.07.2014, Бюл. № 20.

6. Blaya J., López-Mondéjar R., Lloret E., Pascual J., Ros M. Changes induced by Trichoderma harzianum in suppressive compost controlling Fusarium wilt. Pesticide biochemistry and physiology. 2013. Vol. 107, No. 1. P. 112-119. https://doi.org/ 10.1016/j.pestbp.2013.06.001

7. Гаценко М. В., Волкогон М. В., Луценко Н. В., Волкогон В. В. Вплив Pseudomonas putida 17 на накопичення фітогормонів у вермикомпості. Сільськогосподарська мікробіологія. 2011. Вип. 13 С. 82-91.

8. Sharma A., Saha T. N., Arora A., Shah R., Nain L. Efficient microorganism compost benefits plant growth and improves soil health in calendula and marigold. Horticultural Plant Journal. 2017. Vol. 3, No. 1. P. 67-72. https://doi.org/10.1016/ j.hpj.2017.07.003

9. Bernal Vicente A., Pascual J. A., Tittarelli F. Trichoderma harzianum T-78 supplementation of compost stimulates the antioxidant defence system in melon plants. J. Sci Food Agric. 2015. Vol. 95, No. 11. P. 2208-2214. https://doi.org/10.1002/ jsfa.6936

10. Біоорганічне добриво: пат. 113809 Україна. МПК C05F15/00, C05F11/02, C05F11/08, C05F17/00, C12R1/885, В. В. Волкогон, С. М. Деркач, С. Б. Дімова, М. В. М'ягка, Л. Т. Наконечна, Н. В. Луценко; заявник і патентовласник: Інститут сільськогосподарської мікробіології та агропромислового виробництва НААН. № а 201512845; заявл. 25.12.2015; опубл. 10.03.2017, Бюл. № 5.

11. Волкогон В. В. Дімова С. Б., М'ягка М. В., Деркач С. М., Луценко Н. В., Штанько Н. П., Центило Л. В. Біокомпостування пташиного посліду асоціацією грибів Trichoderma harzianum
128. Вісник аграрної науки. 2016. № 11. С. 13-18. https://doi.org/10.31073/agrovisnyk201611-02

12. Деркач С. М., М'ягка М. В., Волкогон В. В., Наконечна Л. Т., Дімова С. Б., Кравченко Н. О., Луценко Н. В. Морфолого-культуральні та фізіолого-біохімічні особливості штамів мікроміцетів, що входять до складу асоціації Trichoderma harzianum 128. Сільськогосподарська мікробіологія. 2018. Вип. 28. С. 17-26. https://doi.org/10.35868/ 1997-3004.28.17-26

13. Драговоз И. В., Я Яворская В. К., Антонюк В. П., Курчий Б. А. Гормональные соединения, продуцируемые ассоциацией микроорганизмов из ризосферы женьшеня. Физиология $u$ биохимия культ. растений. 2009. Т. 41, № 5. C. 393-399.

14. Методы экспериментальной микологии: справочник / под ред. В. И. Билай. Київ : Наук. Думка, 1982. 561 с.

15. Методические рекомендации по определению фитогормонов. Киев : Ин-т ботаники АН УССР, 1988. $78 \mathrm{c}$.

16. Lee I. J., Foster K. R., Morgan P. W. Photoperiod control of gibberellin levels and flowering in sorghum. Plant Physiol. 1998. Vol. 116, № 3. P. 1003-1011. https://doi.org/10.1104/pp.116.3.1003

17. Полевой В. В. Фитогормоны. Л. : ЛГУ, 1982. 245 c.

18. Борзова Н. В., Варбанець Л. Д. Целюлозодеградуючі системи мікроорганізмів: біосинтез, властивості та структурнофункціональні особливості. Біотехнологія. 2009. Т. 2, № 2. C. $23-41$.

19. Аверина Н. Г., Яронская Е. Б. Биосинтез тетрапирролов в растениях. М. : Беларус. Наука, 2012. 413 c. 